\title{
Evolution of primary production and its drivers on the Lebanese coast between 1986 and 2013
}

\author{
Ali Fadel ${ }^{1, *}$, Lama Salameh ${ }^{2}$, Malak Kanj $^{3}$, Ahmad Kobaissi' $^{2}$ \\ ${ }^{1}$ National Center for Remote Sensing, National Council for Scientific Research (CNRS), P.O. Box 11-8281, Riad El Solh, \\ 11072260 Beirut, Lebanon, e-mail: afadel@cnrs.edu.lb (*corresponding author) \\ ${ }^{2}$ Lebanese University, Faculty of Sciences, P.O. Box 6573/14 Badaro, Museum, Hadath, Lebanon \\ ${ }^{3}$ Mediterranean Agronomic Institute of Chania, Department of Geoinformation in Environmental Management, P.O. Box 85, \\ Alsyllio Agrokepiou, 73100 Chania, Greece, e-mail: mkanj@maich.gr
}

\begin{abstract}
Physical-biogeochemical models help us to understand the dynamics and the controlling factors of primary production. In this study, the outputs of a validated hydrodynamic and biogeochemical model were used to elucidate the primary production dynamics between 1992 and 2012 for three studied sites on the Lebanese coast: Naqoura, Beirut, and Tripoli. The results showed that primary production presents a homogeneous spatial distribution along the Lebanese coastline. The phytoplankton community has a low optimal temperature. The thermocline develops in March, with maximum stratification in August and fades in October. Chlorophyll, dissolved oxygen and salinity were positively correlated throughout the water column. A significant increasing trend of sea surface temperature was found on the Lebanese coast over 27 years, between 1986 and 2013. Annual averages increased from $22^{\circ} \mathrm{C}$ in 1986 to $23.1^{\circ} \mathrm{C}$ in 2013 with the highest recorded average temperature of $23.7{ }^{\circ} \mathrm{C}$ in 2010.
\end{abstract}

Key words: temperature, nutrients, chlorophyll, dynamics, global warming

\section{Introduction}

The coastlines of the worlds' seas and oceans are the most dynamic environments and encompass a wide variety of geomorphic features. Coastal areas are characterized by high production due to high phytoplankton biomasses and biodiversity. The phytoplankton community forms the base of the marine food chain that represents the most important source of organic material and forms the base of marine food web. It plays a key role in biogeochemical cycles and in marine fisheries (Kyewalyanga 2014; Reynolds 2006). Coastal environments differ in their physical and hydrographic properties such as depth, tidal stirring and nutrient loadings, which can lead to complex phytoplankton dynamics (Polat et al. 2005). Climate change can affect primary production by altering the physical and chemical properties of the ecosystem (Kyewalyanga 2014), through changes in stratification, circulation and temperature (Fadel et al. 2019; Mhawej et al. 2020; Slim et al. 2014).

Phytoplankton can be controlled by the vertical density structure of the water column, such as stratification that has a major impact on primary production (Fadel et al.,2015; Ruardij et al. 1997). Environmental factors and weather conditions, for example, an increase in storm frequency and rainfall or changes in wind speed and direction, can impact water properties (e.g. salinity, mixing, and turbidity) and thereby primary production (Chen et al. 2012; Elmadani et al. 2011; Fadel 2014).

Coastal zones and shelf seas are affected by erosion and land degradation (Darwish and Fadel 2017; Ghoussein et al. 2018), high pressure of human activities such as fishing, waste water discharge, dredging, fossil fuel extraction and offshore energy generation (Wakelin et al. 2015). These anthropogenic inputs to water and sediment increase the concentration of chemical contaminants that are potentially toxic to aquatic organisms (Fadel and Slim 2018). 
Marine waters can also suffer from harmful algal blooms (HABs or red tides) that can be a nuisance to aquatic organisms like fish and shellfish (Fadel et al. 2014), the environment, as well as humans, and can also cause economic losses (Kyewalyanga 2014).

Ecosystems are dynamic systems and the study of their evolution requires the development of models in order to study the complex physicalbiogeochemical interactions between the atmosphere and the surface ocean controlling marine ecosystems (Kanj and Fadel 2020). Meanwhile aquatic ecosystems and phytoplankton can be monitored by costly field sampling and laboratory analysis or by remote sensing that can be limited by cloud cover (El Hourany et al. 2017; Ghoussein et al. 2019; Pinardi et al. 2018; Sharaf et al. 2019). Models offer a way to synthesize our understanding of the environment, analyse changes in ecosystems, and forecast future changes (Fadel et al. 2019; Jickells et al. 2015). Hydrodynamicecological models can help us to understand the dynamics and the controlling factors of primary production (Fadel et al. 2017; Roy et al. 2016; Sharip et al. 2016; Vinçon-Leite et al. 2017).

In the Mediterranean, modelling studies have beenconducted to study the evolution of the physical, chemical, and biological parameters. However, hydrodynamic-ecological modelling studies on the Lebanese coast are poorly documented. In this study, we: (i) describe the evolution of the different biological and chemical-physical parameters at the Lebanese coast between 1999 and 2012, (ii) determine the environmental factors controlling primary production on the Lebanese coast, and (iii) assess whether the Lebanese coast is affected by climate change.

\section{Study site}

The Mediterranean Sea is a semi-enclosed water basin, covering about 2.5 million $\mathrm{km}^{2}$ and divided into western and eastern basins. It is characterized by a semi-arid climate, low precipitation and low river input. It is a hotspot for marine biodiversity with a general decrease in biodiversity from the north-western to the southeastern regions. Biodiversity is also generally higher in coastal areas and continental shelves, although it decreases with depth (Coll et al. 2010).
The eastern part is oligotrophic with phosphorus being the most limiting nutrient, followed by nitrogen (Estrada 1996). The Lebanese coast is located in Asia, in the eastern part of the Mediterranean basin, with an extent of $220 \mathrm{~km}$. The marine ecosystem is not productive as it is nutrientpoor. However, it is highly exposed to polluting activities, mainly effluents of solid and liquid wastes from industrial discharges. The continental shelf is quite narrow, with the widest part at only $12 \mathrm{~km}$ in the north. The tidal range is slight, averaging from $15-30 \mathrm{~cm}$, with a maximum up to $50 \mathrm{~cm}$. Sea surface temperature varies between $16^{\circ} \mathrm{C}$ in winter and $30^{\circ} \mathrm{C}$ in summer. The general circulation along the Lebanese coast is dominant in a northward direction during most of the year, in accordance with the general counter clockwise current gyre of the Eastern Mediterranean. The phytoplankton and zooplankton communities are wide in range, with significant seasonal variation in species composition, distribution, and abundance. Three study positions located along the Lebanese coast (Fig. 1): Tripoli (north), Beirut (middle) and Naqoura (south), were chosen in this study in order to assess the evolution of its bio-physicochemical parameters.

Few studies have been carried out on the variations of primary production in the Lebanese coastal area. The first conducted study, in 1973, found that chlorophyll-a was generally high during the summer and low during the winter (Hardy and Jubayli 1976). During 1982 it was found that the phytoplankton community was composed mainly of diatoms (Saab 1992). Leptocylindrus danicus was dominant and was positively correlated to total phytoplankton and total diatom concentrations. An increased frequency of Ostreopsis siamensis blooms started in 1979, and began to grow in density at most of the rocky littoral stations between May and November, reaching 10560 cells per $\mathrm{dm}^{3}$ in July 2001. In 2008 and 2009, this species was found in February, March and April in small numbers (Abboud-Abi Saab 2010). A catastrophic oil spill occurred on the Lebanese coast during Summer 2006 and lasted for one month. According to Khalaf et al. (2006) primary production showed a serious qualitative and quantitative impact in the 2 months following the catastrophe. According to AbboudAbi Saab (2010) in the absence of thermal stability, changes in meteorological conditions directly influenced phytoplankton populations. 


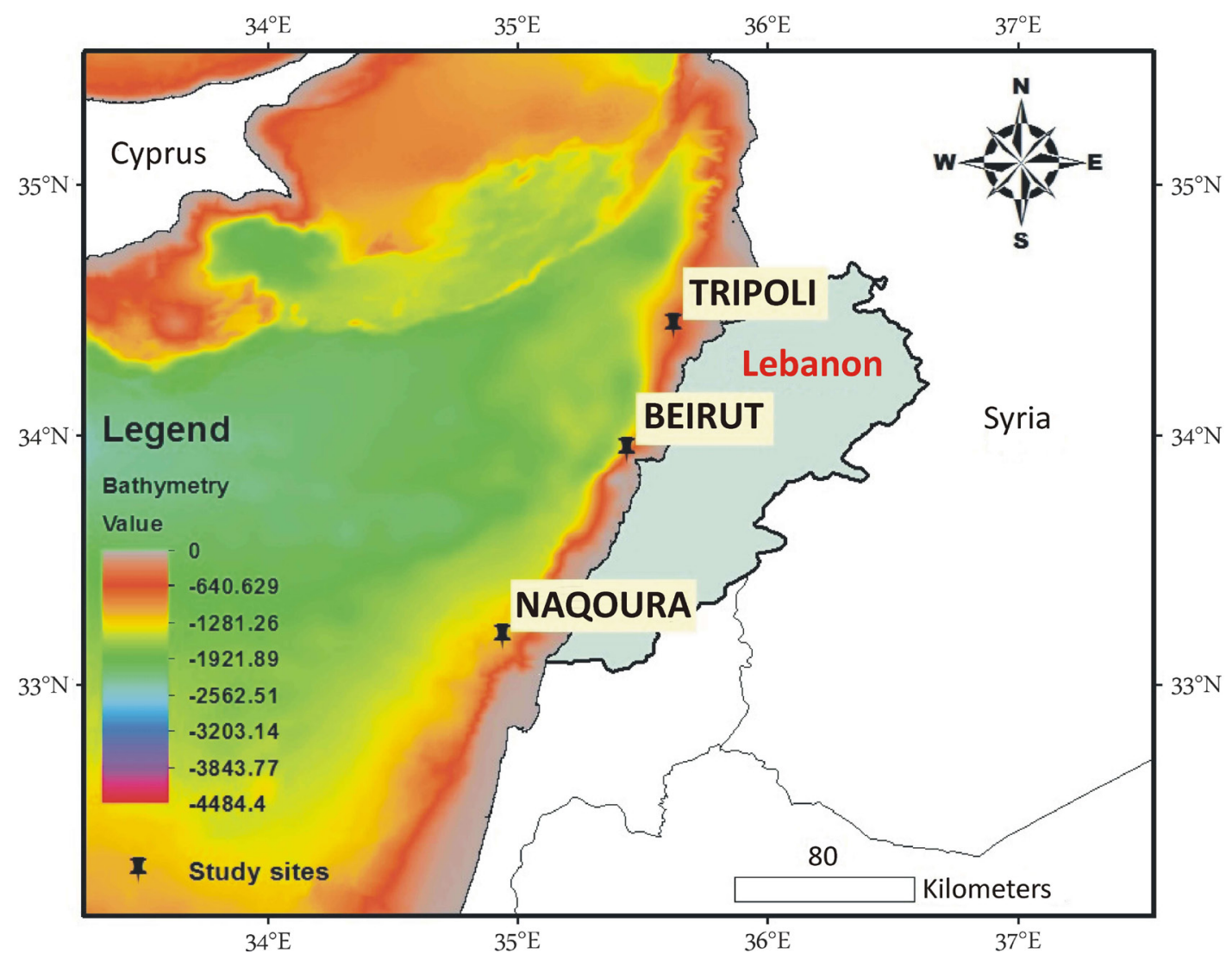

Fig. 1. Study sites on the Lebanese coast

\section{Materials and methods}

Data acquisition and treatment

The outputs of two models developed and validated previously for the Mediterranean Sea were used to monitor chlorophyll- $a$, phytoplankton biomass concentrations, seawater temperature, salinity, nitrogen, phosphate and dissolved oxygen. The Mediterranean Forecasting System, physical reanalysis component (MED REA), which is a hydrodynamic model, was used to determine salinity levels and temperatures. This hydrodynamic model was supplied by the Nucleus for European Modelling of the Ocean (NEMO). It provides water temperatures and salinity vertical profiles, satellite Sea Level Anomaly along track data and horizontal velocity. The data is available for 27 years (19872013) with a horizontal resolution of $1 / 16$ degree. The quality of the MED REA system has been assessed and found to be acceptable with a low
Root Mean Square Error (RMSE).

The biogeochemical model (OPATM-BFM) Océan Parallelisé Transport Model-Biogeochemical flux model, is a three dimensional ecosystem model that was a result of long-term research on the biogeochemical characteristics of the Mediterranean Sea. (OGS) The Istitito Nazionale di Oceanografia e di Geofisica Sperimentale in Italy has developed this model within a series of Italian and European projects.

The reanalysis of Mediterranean Sea biogeochemistry at $1 / 16$ degree has been achieved using the OPATM-BFM biogeochemical model data assimilation of surface chlorophyll concentration between 1999 and 2012. According to Fratianni et al 2016, an average RMS of $0.34^{\circ} \mathrm{C}$ was reported for temperature and 0.1 psu for salinity through the water profile. (Fratianni et al., 2016). The quality of the data supplied by the OPATM-BFM has been assessed by comparing the results with observational datasets, derived by satellite and by experimental research cruises. 
Teruzzi et al. (2015) found that the relative bias between the model and observations for the whole Mediterranean area did not exceed $30 \%$, except for phosphate in the upper layer. The model bias is 13 to $17 \%$ for nitrate, 27 to $39 \%$ for phosphate, and 2 to $7 \%$ for dissolved oxygen. The performance of the model in terms of bias for surface chlorophyll- $a$ (top $200 \mathrm{~m}$ ) is better in winter than in summer (chlorophyll values usually order $0.005 \mathrm{mg} \mathrm{m}^{-3}$ ), when the model tends to slightly underestimate the satellite values in summer where chlorophyll bias is usually $-0.02 \mathrm{mg} \mathrm{m}^{-3}$ (Teruzzi et al. 2015).

Data analysis

Data were extracted using Panoply software for further treatment and analysis using Excel and MATLAB. Physical variables were available from the period of 1887 to 2013 with no gaps. Biochemical variables were also available from the period of 1999 to 2012 with no gaps. All these data had the same depth, with a range between 1.5 and 1011 $\mathrm{m}$, as monthly averages.

Different averages were then performed on the retrieved data to plot, visualize and discuss. An average of the vertical profiles was performed to plot and create the variation of each parameter with respect to time. On the other hand, averages of the values at different dates plotted at every depth were also averaged to create profiles showing the vertical variation of these parameters. This process was conducted for each study point on the Lebanese coast.

\section{Results}

Vertical variation of primary production and their drivers averaged between 1999 and 2012

The concentration of chlorophyll was 0.07 $\mathrm{mg} \mathrm{\textrm {m } ^ { - 3 }}$ at the top $40 \mathrm{~m}$ depth. It increased to reach a maximum of about $0.1 \mathrm{mg} \mathrm{m}^{-3}$ at an $80 \mathrm{~m}$ depth in the three studied locations (Fig. 2a). The concentration then decreased to become negligible after a depth of $300 \mathrm{~m}$.

Water temperature showed the same vertical variation in the three studied sites of the Lebanese coast. The highest temperature of $23^{\circ} \mathrm{C}$ was recorded at the surface and the lowest, of $13^{\circ} \mathrm{C}$, was recorded below $300 \mathrm{~m}$ (Fig. 2b). The thermocline occurred between a 40 and $80 \mathrm{~m}$ depth. Salinity was high at the sea surface, 39.22 in Naqoura, 39.25 in Beirut, and 39.27 in Tripoli. It decreased progressively to 38.8 at a $1000 \mathrm{~m}$ depth in the three studied sites (Fig. 2c).

In all the studied Lebanese sites, phosphorus (Fig. 2d) and nitrogen (Fig. 2e) concentrations were


- Beirut

Tripoli

Naqoura
Fig. 2. Vertical variation of chlorophyll- $a$ (A), temperature (B), salinity (C), phosphorus (D), nitrogen $(\mathrm{E})$, dissolved oxygen $(\mathrm{F})$, and phytoplankton biomass (G), averaged between 1999 and 2012 
lowest between the surface and a depth of $80 \mathrm{~m}$. The concentration increased respectively with depth.

The concentration of phytoplankton biomass was about $0.00044 \mathrm{~mol} \mathrm{~m}^{-3}$ at the top $40 \mathrm{~m}$ depth in the three regions, as shown in Figure $2 \mathrm{~g}$. It increased to a reach a maximum range of between 0.00055 and 0.00065 at a depth of $80 \mathrm{~m}$ (Fig. $2 \mathrm{a})$. The concentration decreased progressively to become negligible after a depth of $250 \mathrm{~m}$.

In the Mediterranean basin a stratification period and a mixing period alternated during the seasonal cycle. The development of the thermocline began between March and April (Fig. 3 ), when the water temperature started to increase. The stratification of the water column progressed throughout the summer, with maximum stratification in August. Thermal stratification then weakened gradually between September and March.

Spatial-temporal variation of primary production and their drivers

On a seasonal basis, the chlorophyll- $a$ concentration had one main peak in March-April (0.06 $\mathrm{mg} \mathrm{m}^{-3}$ for Tripoli, $0.05 \mathrm{mg} \mathrm{m}^{-3}$ for Beirut, $0.04 \mathrm{mg} \mathrm{m}^{-3}$ for Naqoura) as shown in Figure 4a.
These concentrations decreased to minimum values between 0.018 and $0.025 \mathrm{mg} \mathrm{m}^{-3}$ in July, in the three sites on the Lebanese coast. This trend is correlated with the concentration of dissolved oxygen (Fig. 4b), produced by phytoplankton and with the first peak of phytoplankton biomass (Fig. 4d).

Phytoplankton biomass had two relative peaks (Fig. 4d). The first peak between April and May, and the second one between September and October. The results in Tripoli and Naqoura were very close, while in Beirut it was lower, with 0.0003 mol m${ }^{-3}$ in Beirut and $0.0005 \mathrm{~mol} \mathrm{~m}^{-3}$ in Naqoura and Tripoli.

Dissolved oxygen reached its highest concentration of $203 \mathrm{mmol} \mathrm{m} \mathrm{m}^{-3}$ between April and May. It decreased progressively to a minimal of 196 mmol $\mathrm{m}^{-3}$ between August and December in the three locations (Fig. 4b).

The seasonal dynamics of water temperature means, which were averaged on the whole water column (1000 m), showed a seasonal cycle (Fig. 4g), with a low range of variability between the three studied sites, and a similar trend with maximum average temperatures reaching $18.5^{\circ} \mathrm{C}$ in August and low temperatures reaching $16^{\circ} \mathrm{C}$ in March for all three locations.

The development of the thermocline started
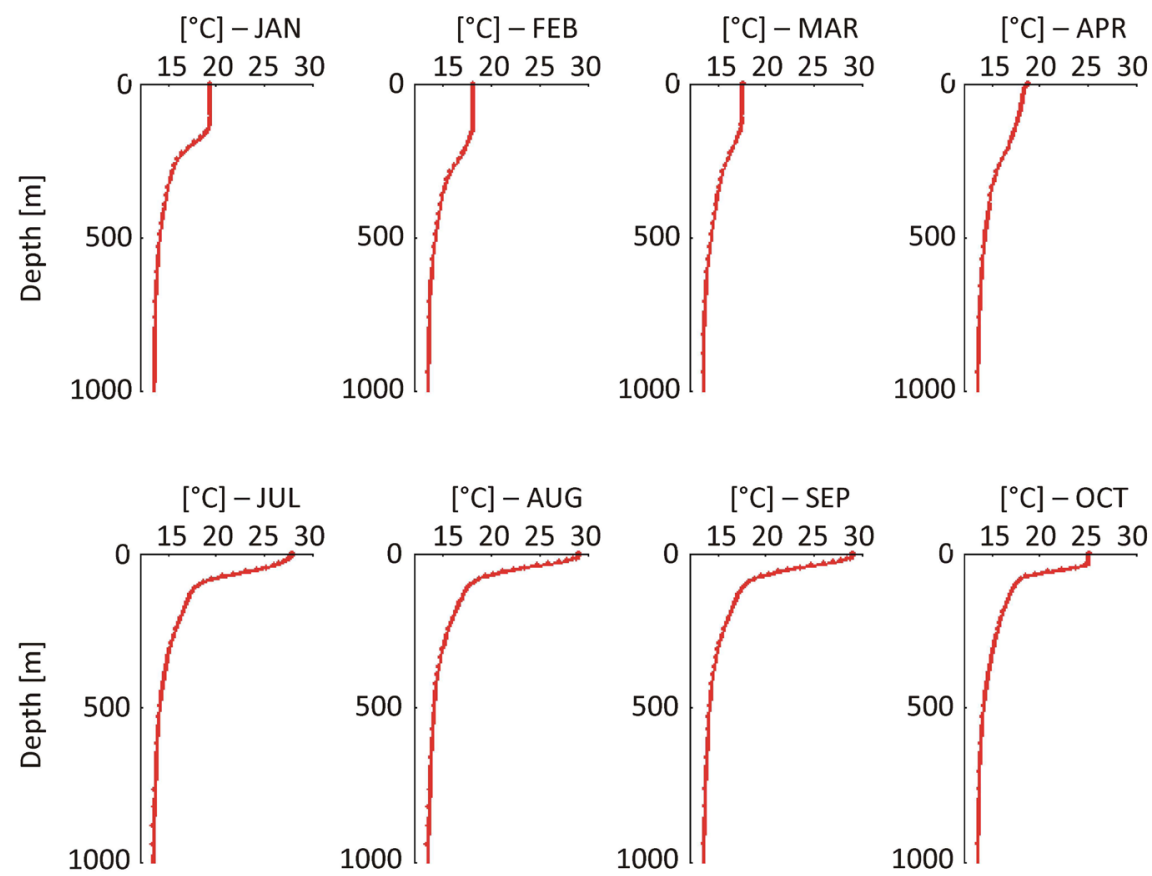
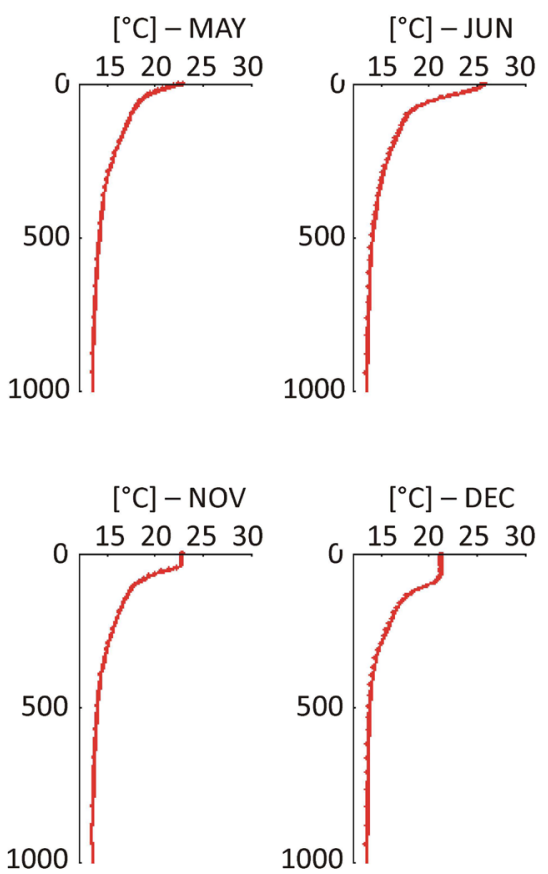



Fig. 3. Development of the thermocline on the Lebanese coast 
between March and April, when water temperature begins to increase, and the stratification of the water column progresses throughout the summer where it occurs with its maximum in August and begins to disappear in October and allows nutrients to be brought to the surface (Fig. 3).

Figure $4 \mathrm{f}$ shows that variability in sea water salinity was very low and stayed in the range of 39 with the highest values of $\mathbf{3 9 . 0 6}$ in December and January for the three sites, and the lowest, of 39, for the Tripoli and Beirut locations and $\mathbf{3 8 . 9 8}$ for the Naqoura site.

As the results show, the concentration of nitrate was at its highest between February and March in Beirut, reaching almost $1.75 \mathrm{mmol}$ $\mathrm{m}^{-3}$, while in Tripoli and Naqoura, there was no relative difference in the concentration of Nitrate between these two months (1.625-1.675 mmol $\mathrm{m}^{-3}$ ). The concentration decreased relatively to reach a minimum of $1.55 \mathrm{mmol} \mathrm{m}^{-3}$ in the three regions between April and May after which the concentration increased progressively between March and October.

Nitrogen concentration reached its maximum in winter and the maximum phosphate concentration (Fig. 4c) occurred in summer. Phosphate decreased between February and May, to a minimum of 0.076 $\mathrm{mmol} \mathrm{m} \mathrm{m}^{-3}$ in Beirut, $0.077 \mathrm{mmol} \mathrm{m}^{-3}$ in Tripoli, and
$0.078 \mathrm{mmol} \mathrm{m}^{-3}$ in Naqoura, as shown in Figure $4 \mathrm{e}$. It then increased to reach its maximum in October with $0.084 \mathrm{mmol} \mathrm{m}^{-3}$ in Beirut and Naqoura and $0.083 \mathrm{mmol} \mathrm{m}^{-3}$ in Tripoli.

Table 1 presents the correlation between chlorophyll, proxy of phytoplankton biomass and the other studied factors on the spatial-temporal scale. A significant negative correlation was found between chlorophyll and temperature. No or weak correlation was found between chlorophyll and nutrients.

Table 2 presents the correlation between chlorophyll, proxy of phytoplankton biomass and the other studied factors throughout the water column. A significant positive correlation is noticed between chlorophyll, dissolved oxygen and salinity. A high negative correlation was found between chlorophyll and nutrients, indicating that both studied nutrients (nitrogen and phosphorus) were highly correlated.

A very significant increasing trend of sea surface temperature was found on the Lebanese coast over 27 years, between 1986 and 2013, with $\alpha=0.001$ (Table 3). Sea surface temperature increased from $22^{\circ} \mathrm{C}$ in 1986 to $23.1^{\circ} \mathrm{C}$ in 2013 with highest recorded temperature of $23.7{ }^{\circ} \mathrm{C}$ in 2010 (Fig. 5).

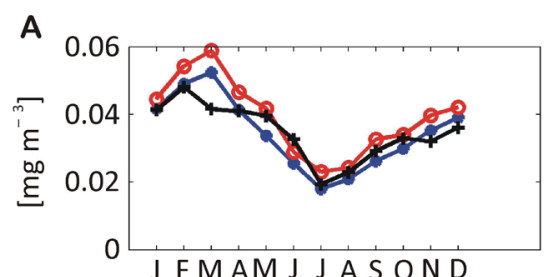

D



G



B



E

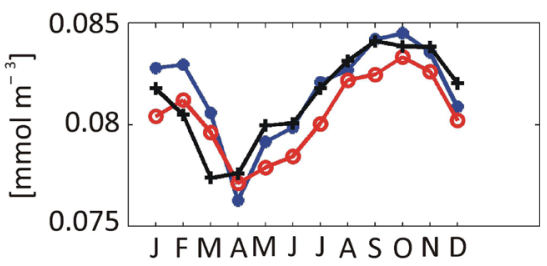

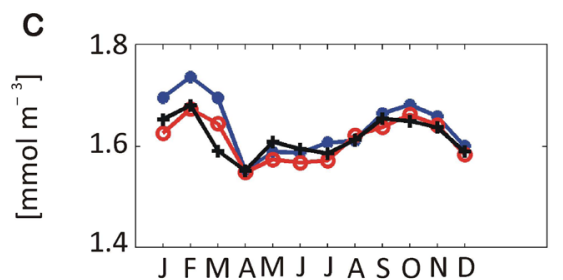

$\mathbf{F}$

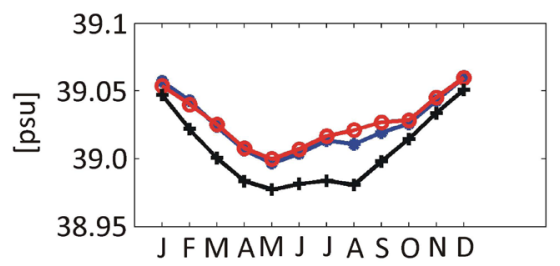

ig. 4. Temporal variation of an average of the whole water column of chlorophyll- $a(\mathrm{~A})$, dissolved oxygen (B), nitrogen (C), phytoplankton biomass (D), phosphorus (E), salinity $(\mathrm{F})$, and temperature $(\mathrm{G})$, averaged between 1999 and 2012 
Table 1. Correlation between the different studied parameters on the Lebanese coast ( 3 sites), based on their spatial-temporal variation

\begin{tabular}{cccccccc}
\hline & Chl $-a$ & DO & Nitrogen & Pcb & Phosphate & Salinity & Temperature \\
\hline Chl- $a$ & 1 & & & & & & \\
DO & 0.406898 & 1 & & & & & \\
Nitrogen & 0.284923 & -0.46604 & 1 & & & & \\
Pcb & -0.02996 & 0.418138 & -0.42154 & 1 & & & \\
Phosphate & -0.36472 & -0.88357 & 0.685620 & -0.28372 & 1 & & \\
Salinity & 0.364789 & -0.54835 & 0.457395 & -0.63528 & 0.331664 & 1 \\
Temperature & -0.84712 & -0.75000 & 0.046148 & -0.02044 & 0.695459 & -0.04790 & 1 \\
\hline
\end{tabular}

Table 2. Correlation between the different studied parameters on the Lebanese coast ( 3 sites), based on their vertical variation throughout the water column

\begin{tabular}{cccccccc}
\hline & Temperature & Chl- $a$ & DO & Nitrogen & Phosphate & Salinity & Pcb \\
\hline Temperature & 1 & & & & & & \\
Chl- $a$ & 0.848826 & 1 & & & & & \\
DO & 0.682468 & 0.832222 & 1 & & & & \\
Nitrogen & -0.92216 & -0.92964 & -0.90402 & 1 & & & \\
Phosphate & -0.94507 & -0.94090 & -0.87405 & 0.996855 & 1 & & \\
Salinity & 0.966608 & 0.823663 & 0.770518 & -0.95281 & -0.95877 & 1 \\
Pcb & 0.882853 & 0.945400 & 0.714117 & -0.86754 & -0.89490 & 0.799639 & 1 \\
\hline
\end{tabular}

Table 3. Mann-Kendall Test and Sen's Slope Estimates for the trend of water temperature between 1987 and 2013

\begin{tabular}{cc}
\hline TsNumber & 1 \\
\hline Name & Temperature \\
\hline Years & $1987-2013$ \\
\hline $\mathrm{n}$ & 27 \\
\hline Test Z & 4.54 \\
\hline Significance & $* * *$ \\
\hline Q & $4.56 \mathrm{E}-02$ \\
\hline Qmin99 & $2.68 \mathrm{E}-02$ \\
\hline Qmax99 & $6.74 \mathrm{E}-02$ \\
\hline Qmin95 & $3.31 \mathrm{E}-02$ \\
\hline Qmax95 & $5.89 \mathrm{E}-02$ \\
\hline B & $2.22 \mathrm{E}+01$ \\
\hline Bmin99 & $2.24 \mathrm{E}+01$ \\
\hline Bmax99 & $2.19 \mathrm{E}+01$ \\
\hline Bmin95 & $2.24 \mathrm{E}+01$ \\
\hline Bmax95 & $2.20 \mathrm{E}+01$ \\
\hline
\end{tabular}

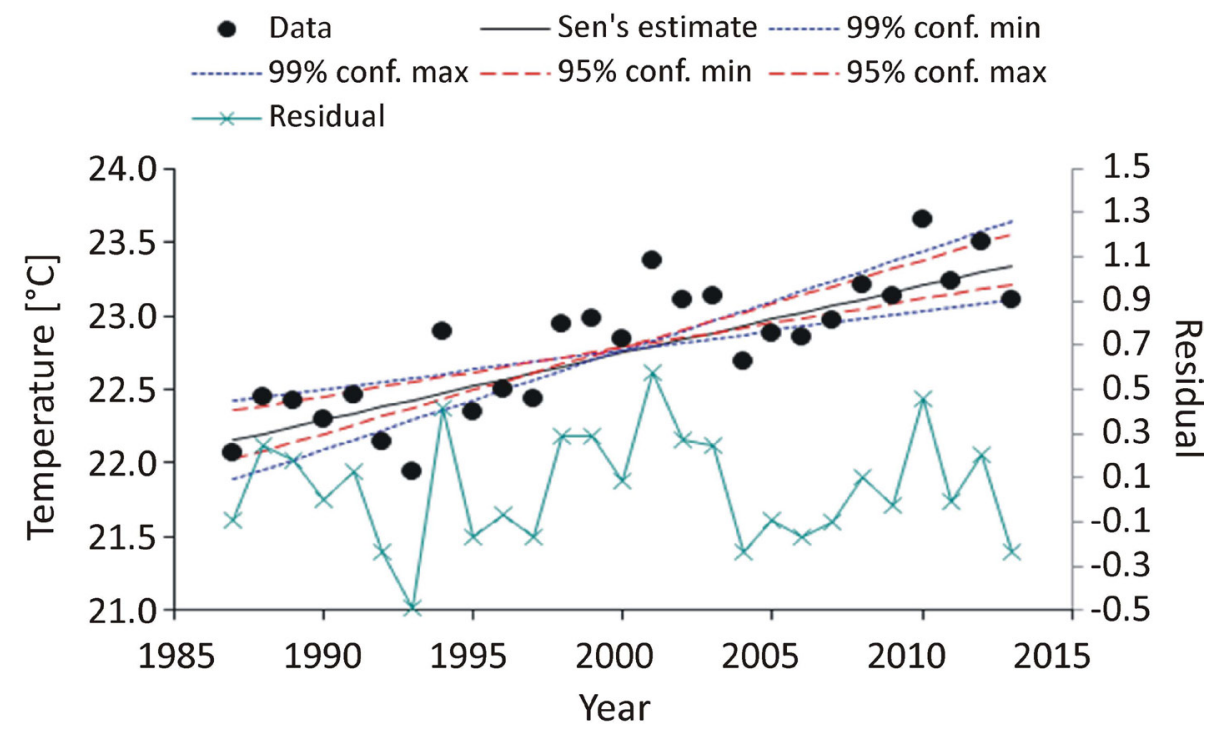

Fig. 5. Evolution of average sea surface temperature between 1887 and 2013 on the Lebanese coast, Beirut 


\section{Discussion}

A significant negative correlation was found between chlorophyll and temperature in thestudy site for temporal data, suggesting that the phytoplankton community has a low optimal temperature and that an increase in water temperature can result in their loss. No or weak correlation was found between chlorophyll and nutrients. Fakhri et al. (2005) found that high levels of nutrients essential for phytoplankton development did not result in high chlorophyll-a concentrations on the Lebanese coast. The reduction in chlorophyll-a concentrations was the consequence of the dystrophic condition caused by the unbalance in nutrient distribution and the destructive effect of acid discharges at primary production level (Fakhri et al. 2005). Low correlation between chlorophyll and phytoplankton biomass can be due to factors like wind and mixing (Vörös and Padisák 1991). The upward movement of bottom and the sedimented planktonic algae or horizontal displacement by wind action can have a considerable influence on the correlation between planktonic biomass and chlorophyll. Further, the relation between chlorophyll- $a$ concentration and biomass might be influenced by the size of the algal cells where the dry-matter content of smaller cells is higher than that of larger cells (Margalef 1954). Smaller algae contain not only more dry matter and organic carbon, but also more chlorophyll- $a$ (Malone 1980).

For the vertical profiles data, low correlation was noted between chlorophyll and nutrients through the water column, as shown in Table 2. This can be due to the increase of nutrient concentration with depth (Hopkinson and Wetzel 1982) and a decrease of phytoplankton biomass due to the absence of light in deep layers (Litchman 2000). Another possible cause of this negative correlation might be the abundance of nutrients and phytoplankton growth limitation by other factors like wind and zooplankton grazing (Gallegos and Jordan 1997).

The Mediterranean Sea ranks among the fast warming regions of the world due to its relatively small volume. There is evidence for impacts of climate change on marine Mediterranean organisms but a quantitative assessment is lacking. Global warming has raised the average global temperature over the past century. The 100-year linear trend of water temperature between 1906 and 2005 is 0.74 [0.56 to 0.92$]^{\circ} \mathrm{C}$ (IPCC 2007). In monitoring oceanographic conditions of the Lebanese neritic seawater since 1965, Lakkis (2004) noticed certain hydrological changes in the Levantine Basin, expressed by small rises in temperature $\left(\Delta \mathrm{T}=0.4^{\circ} \mathrm{C}\right)$ and salinity $(\Delta \mathrm{S}=0.35 \%)$ and increasing migration.

Temperature plays a critical role in resource allocation and marine phytoplankton stoichiometry, with implications for the biogeochemical cycles that they drive (Toseland et al. 2013). Climate change may lead to numerous local extinctions in the subpolar regions, the tropics and semi-enclosed seas (Toseland et al. 2013). A decrease of up to $20 \%$ in the phytoplankton community has been reported in the western Indian Ocean over the past six decades (Roxy et al. 2016). Some phytoplankton species are harmful and can produce toxins or constitute a nuisance to other species, including humans. Global warming may cause increasing numbers of $\mathrm{HABs}$ to appear in coastal regions (Heip et al. 2009).

The ocean ecosystem is affected by temperature changes that can influence the pattern of marine biodiversity through changes in species' distributions. Changes in temperature and salinity have influenced the ecology of marine resources and the biodiversity of flora and fauna on the Lebanese coast. The opening of the Suez Canal in 1869 increased the number of exotic invaders.

Around 400 species of phytoplankton were reported on the Lebanese coast. Dozens of these species are of Indo-Pacific origin (Lakkis 2004). About $20 \%$ of the identified zooplankton community $(900$ species), were Lessepsian migrants. Concerning the macroalgue species, $20 \%$ out of 240 identified are biological invaders originating from the Red Sea. About $21 \%$ of the Ichtyofauna (350 species) are of Indo-Pacific origin. Lakkis and Sabour (2014) believe that the rise in water temperature and salinity levels, together with the reduced marine resources has prompted the "tropicalization" of the Levantine Sea. This is not only a result of anthropic activity induced by the opening of the Suez Canal and the building of the Aswan High Dam, but also of climatic change leading to global warming (Lakkis and Sabour 2014). 


\section{Conclusion}

This work examined primary production at the Lebanese coast and described the evolution of different physical and biochemical variables between 1999 and 2012. Chlorophyll and nutrient concentrations were low, classifying this study area as oligotrophic. Biological parameters displayed high concentrations with low nitrate and phosphate, associated with higher dissolved oxygen saturation.

Salinity did not show great variability. Sea temperatures varied with seasonal fluctuations, with high values in August and lower ones in March. In addition, thermal stratification had a significant effect on primary production through the establishment of the thermocline that caused vertical variations in nutrient distribution. Stratification started between March and April, reached its maximum in August and started to weaken in October allowing nutrients to be move upward through the water column.

Similar trends in water variables were demonstrated for all three studied sites. However, industrial activities along the Lebanese coast, especially in Beirut, have led to high nutrient inputs. A significant negative correlation was found between chlorophyll and temperature, suggesting that the phytoplankton community has a low optimal temperature and an increase in water temperature could result in their loss. Throughout the water column, chlorophyll, dissolved oxygen and salinity were positively correlated. A high negative correlation was found between chlorophyll and nutrients, due to their possible consumption by phytoplankton in the euphotic zone and to the increase of nutrient concentrations with depth. A significant increasing trend of sea surface temperature was found on the Lebanese coast over the 27 years between 1986 and 2013 . It increased from $22^{\circ} \mathrm{C}$ in 1986 to $23.1^{\circ} \mathrm{C}$ in 2013 , with the highest recorded temperature of $23.7{ }^{\circ} \mathrm{C}$ in 2010. This heightens the need to examine how climate change will affect biodiversity, and how the production of marine ecosystems will change under current predictions of climate change.

The information provided by this study shows that ecosystem modelling and its outputs could be an effective tool for monitoring water quality variables over large spatial and time scales. This will improve the understanding and assessment factors associated with primary production.

\section{Acknowledgments}

This work was supported by the National Council for Scientific Research - Lebanon.

\section{References}

Abboud-Abi Saab M., 2010, Studies and changes of phytoplankton populations in Lebanese coastal waters - a brief overview, [in:] Briand F. (ed.), Phytoplankton responses to Mediterranean environmental changes. CIESM Workshop Monographs No. 40, CIESM Publisher, Monaco: 79-82.

Chen X., Yang X., Dong X., Liu E., 2012, Influence of environmental and spatial factors on the distribution of surface sediment diatoms in Chaohu Lake, southeast China, Acta Bot. Croat. 71(2): 299-310.

Coll M., Piroddi C., Steenbeek J., Kaschner K., Ben F., Lasram R., Ballesteros E., Bianchi C.N., Corbera J., Dailianis T., Kesner-Reyes K., Kitsos M., RiusBarile J., Martin D., Mouillot D., Oro D., Villanueva R., Voultsiadou E., 2010, The Biodiversity of the Mediterranean Sea: Estimates, patterns, and threats PLoS One 5(8): e11842.

Darwish T., Fadel A., 2017, Mapping of soil organic carbon stock in the Arab countries to mitigate land degradation, Arab. J. Geosci. 10(21): e474.

El Hourany R., Fadel A., Gemayel E., Abboud-Abi Saab M., Faour G., 2017, Spatio-temporal variability of the phytoplankton biomass in the Levantine basin between 2002 and 2015 using MODIS products, Oceanologia 59(2): 153-165.

Elmadani F., Chiaar A., Chafi A., 2011. Phytoplankton composition and abundance assessment in the Nador Lagoon (Mediterranean Coast of Morocco), Acta Bot. Croat. 70(2): 269-288.

Estrada M., 1996, Primary production in the northwestern Mediterranean, Sci. Mar. 60(Supl. 2): 55-64.

Fadel A., 2014, Physico-chemical functioning and development of phytoplankton in Karaoun reservoir (Lebanon): application of a hydrodynamic-ecological model [PhD Thesis], Université Paris-Est, Paris, 231 pp.

Fadel A., Atoui A., Lemaire B., Vinçon-Leite B., Slim K., 2014, Dynamics of the toxin cylindrospermopsin and the cyanobacterium Chrysosporum (Aphanizomenon) ovalisporum in a Mediterranean eutrophic reservoir, Toxins 6(11): 3041-3057.

Fadel A., Atoui A., Lemaire B.J., Vinçon-Leite B., Slim K., 2015, Environmental factors associated with phytoplankton succession in a Mediterranean reservoir with a highly fluctuating water level, Environ. Monit. Assess. 187(10): e633.

Fadel A., Lemaire B.J., Vinçon-Leite B., Atoui A., Slim K., Tassin B., 2017, On the successful use of a simplified model to simulate the succession of 
toxic cyanobacteria in a hypereutrophic reservoir with a highly fluctuating water level, Environ. Sci. Pollut. Res. 24(26): 20934-20948.

Fadel A., Sharaf N., Siblini M., Slim K., Kobaissi A., 2019, A simple modelling approach to simulate the effect of different climate scenarios on toxic cyanobacterial bloom in a eutrophic reservoir, Ecohydrol. Hydrobiol. 19(3): 359-369.

Fadel A., Slim K., 2018, Evaluation of the physicochemical and environmental sStatus of Qaraaoun Reservoir, [in:] Shaban A., Hamze M. (eds.), The Litani River, Lebanon: An assessment and current challenges, Springer, Cham: 71-86.

Fakhri M., Romano J., Abboud M., Saab A., 2005, Impact of natural and artificial chemical inputs on the marine ecosystem of batroun region (North Lebanon), Leban. Sci. J. 6(1): 13-28.

Fratianni C., Clementi E., Simoncelli S., 2016, Quality Information Document for Med Physics reanalysis product: MEDSEA_REANALYSIS _ PHY_006_004. Issue 1.2, Copernicus Marine Monitoring Service (CMEMS), 49 pp.

Gallegos C.L., Jordan T.E., 1997, Seasonal progression of factors limiting phytoplankton pigment biomass in the Rhode River estuary, Maryland (USA). I. Controls on phytoplankton growth, Mar. Ecol. Prog. Ser. 161: 185-198.

Ghoussein Y., Mhawej M., Jaffal A., Fadel A., El Hourany R., Faour G., 2018, Vulnerability assessment of the South-Lebanese coast: A GISbased approach, Ocean Coast. Manag. 158: 56-63.

Ghoussein Y., Nicolas H., Haury J., Fadel A., Pichelin P., Abou Hamdan H., Faour G., 2019 Multitemporal remote sensing based on an FVC reference period using Sentinel-2 for monitoring Eichhornia crassipes on a Mediterranean river, Remote Sens. 11(16): e1856.

Hardy J.T., Jubayli Z., 1976, Phytoplankton standing crop and sewage nutrient enrichment along the central coast of Lebanon, Environ. Pollut. 11(3): 195-202.

Heip C., Hummel,H., van Avesaath P., Appeltans W., Arvanitidis C., Aspden R., Austen M., Boero F., Bouma T.J., Boxshall G., Buchholz F., Crowe T., Delaney A., Deprez T., Emblow C., Feral J.P., Gasol J.M., Gooday A., Harder J., Ianora A., Kraberg A., Mackenzie B., Ojaveer H., Paterson D., Rumohr H., Schiedek D., Sokolowski A., Somerfield P., Sousa Pinto I., Vincx M., Weslawski J., Nash R., 2009, Marine biodiversity and ecosystem functioning, Marine Biodiversity and Ecosystem Functioning EU Network of Excellence Sustainable development, global change and ecosystems (MarBEF), Dublin, 100 pp.
Hopkinson C.S., Wetzel. R.L., 1982, In situ measurements of nutrient and oxygen fluxes in a coastal marine benthic community, Mar. Ecol. Prog. Ser. 10: 29-35.

IPCC, 2007, AR4 Climate change 2007: Synthesis report. Contribution of Working Groups I, II and III to the Fourth Assessment Report of the Intergovernmental Panel on Climate Change [Core Writing Team, Pachauri R.K and Reisinger A. (eds)], IPCC, Geneva, 104 pp.

Jickells T., Andrews J., Barnard S., Tett P., van Leeuwen S., 2015, Natural sciences modelling in coastal and shelf seas, [in:] Turner R.K., Schaafsma M., (eds), Coastal zones ecosystem services: From science to values and decision making, Springer, Cham: 41-58.

Kanj M., Fadel A., 2020, On the use of validated ocean models to investigate the evolution of primary productivity in the Levantine Sea, Limnol. Rev. 20(1): 23-31.

Khalaf G., Nakhlé K., Abboud-Abi Saab M., Tronczynski J., Mouawad R., 2006, Preliminary results of the oil spill impact on Lebanese coastal waters, Leban. Sci. J. 7(2): 135-153.

Kyewalyanga M., 2014, Phytoplankton primary production, [in:] Regional State of the Coast Report. Western Indian Ocean, UN, New York: 213-232.

Lakkis S., 2004, Dataset and database biodiversity of plankton community in Lebanese seawater (Levantine Basin, East Mediterranean), [in:] Van den Berghe E. et al. (eds), Proceedings of Ocean Biodiversity Informatics, Hamburg, Germany 29 November - 1 December, VLIZ Special Publ. 37: 99-112.

Lakkis S., Sabour W., 2014, Global warming inducing "Tropicalization" of the Levantine Basin (East Mediterranean). Does it affect Marine Biodiversity?, Mar. Sci. Coast. Res. 1: 1-17.

Litchman E., 2000, Growth rates of phytoplankton under fluctuating light, Freshw. Biol. 44(2): 223235.

Malone T.C., 1980, Algal size, [in:] Morris I. (ed.), Studies in ecology. The physiological ecology of phytoplankton, Univ. California Press, BerkeleyNew York: 433-463.

Margalef R., 1954, Modifications induced by different temperatures on the cells of Scenedesmus obliquus (Chlorophyceae), Hydrobiologia 6(12): 83-91.

Mhawej M., Fadel A., Faour G., 2020, Evaporation rates in a vital lake: a 34-year assessment for the Karaoun Lake, Int. J. Remote Sens. 41(14): 5321-5337.

Pinardi M., Bresciani M., Villa P., Cazzaniga I., Laini A., Tóth V., Fadel A., Austoni M., Lami 
A., Giardino C., 2018, Spatial and temporal dynamics of primary producers in shallow lakes as seen from space: intra-annual observations from Sentinel-2A, Limnologica 72: 32-43.

Polat S., Akiz A., Olgunoğlu M.P., 2005, Daily variations of coastal phytoplankton assemblages in summer conditions of of the northeastern Mediterranean (Bay of İskenderun), Pak. J. Bot. 37(3): 715-724.

Reynolds C.S., 2006, The ecology of phytoplankton, Cambridge University Press, Cambridge, $535 \mathrm{pp}$.

Roxy M.K., Modi A., Murtugudde R., Valsala V., Panickal S., Kumar S.P., Ravichandran M., Vichi M., Lévy M., 2016, A reduction in marine primary productivity driven by rapid warming over the tropical Indian Ocean, Geophys. Res. Lett. 43(2): 826-833.

Roy U., Majee N.C., Ray S., 2016, Temperature dependent growth rate of phytoplankton and salinity induced grazing rate of zooplankton as determinants of realistic multi-delayed food chain model, Model. Earth Syst. Environ. 2(3): e161.

Ruardij P., Van Haren H., Ridderinkhof H., 1997, The impact of thermal stratification on phytoplankton and nutrient dynamics in shelf seas: a model study, J. Sea Res. 38(3-4): 311-331.

Saab M.A.-A., 1992, Day-to-day variation in phytoplankton assemblages during spring blooming in a fixed station along the Lebanese coastline, J. Plankton Res. 14(8): 1099-1115.

Sharaf N., Bresciani M., Giardino C., Faour G., Slim K., Fadel A., 2019, Using Landsat and in situ data to map turbidity as a proxy of cyanobacteria in a hypereutrophic Mediterranean reservoir, Ecol. Inform. 50: 197-206.
Sharip Z., Saman J.M., Noordin N., Majizat A., Suratman S., Shaaban A.J., 2016, Assessing the spatial water quality dynamics in Putrajaya Lake: a modelling approach, Model. Earth Syst. Environ. 2(1): e46.

Slim K., Fadel A., Atoui A., Lemaire B.J., VinçonLeite B., Tassin B., 2014, Global warming as a driving factor for cyanobacterial blooms in Lake Karaoun, Lebanon, Desalin. Water Treat. 52(1012): 2094-2101.

Teruzzi A., Cossarini G., Salon S., Bolzon G., 2015, Quality Information Document For Mediterranean Sea Biogeochemistry Reanalysis Product MEDSEA_REANALYSIS_BIO_006_008, Copernicus Monitoring Environment Marine Service (CMEMS).

Toseland A., Daines S.J., Clark J.R., Kirkham A., Strauss J., Uhlig C., Lenton T.M., Valentin K., Pearson G.A., Moulton,V., Mock T., 2013, The impact of temperature on marine phytoplankton resource allocation and metabolism, Nat. Clim. Chang. 3(11): 979-984.

Vinçon-Leite B., Fadel A., Lemaire B.J., Bonhomme C., Li Y., Le Divecgen G., Zhang J., Luo Y., 2017, Short-term forecasting of cyanobacteria blooms in Yuqiao reservoir, China, Houille Blanche 2: 35-44.

Vörös L., Padisák J., 1991, Phytoplankton biomass and chlorophyll-a in some shallow lakes in central Europe, Hydrobiologia 215(2): 111-119.

Wakelin S.L., Artioli Y., Butenschön M., Allen J.I., Holt J.T., 2015, Modelling the combined impacts of climate change and direct anthropogenic drivers on the ecosystem of the northwest European continental shelf, J. Mar. Syst. 152: 51-63. 